International and Comparative Corporate Law Journal

\author{
Volume 12 • $2017 \bullet$ Issue 2 \\ Special Issue: Daughters of Themis: \\ International Network of Female \\ Business Scholars \\ Editors: Roseanne Russell \\ and Beate Sjåfjell
}

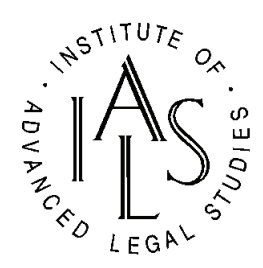

CAMERON

I $\mathrm{MAY}$

INTERNATIONALLAW \&OLICY 
Copyright (C) CMP Publishing

Cameron May is an imprint of CMP Publishing Ltd

Published 2017 by CMP Publishing

UK Email: orders@cmppublishing.com

Website: www.cmppublishing.com

All rights reserved. Except for the quotation of short passages for the purpose of criticism and review, no part of this publication may be reproduced, stored in a retrieval system or transmitted, in any form or by any means, electronic, mechanical, photocopying, recording or otherwise, without prior permission of the publisher.

This journal is sold subject to the condition that it shall not by way of trade or otherwise, be lent, resold, hired out, or otherwise circulated without the publisher's prior consent in any form of binding or cover other than that in which it is published and without a similar condition including this condition being imposed on the subsequent purchaser.

ISSN: $1388-7084$

Printed by Grosvenor Group

To subscribe please contact CMP Publishing Ltd

Annual subscription price (paper) $£ 185.00$ or (Multi User PDF) $£ 350$ 


\title{
INTRODUCING DAUGHTERS OF THEMIS: INTERNATIONAL NETWORK OF FEMALE BUSINESS SCHOLARS
}

\author{
Roseanne Russell and Beate Sjåfjell ${ }^{1}$
}

\begin{abstract}
This special issue of the International and Comparative Corporate Law Journal is the result of the inaugural workshop of Daughters of Themis: International Network of Female Business Scholars. ${ }^{2}$ The workshop was held in Vourvourou, Greece in June 2015, and brought together a range of international scholars from different disciplinary perspectives. Participants were invited to consider how the regulatory environment might be reshaped to meet societal problems that Europe is facing; the interface of business law and feminist theory; empirical studies on the position and impact of women in business; or more reflective contributions on being a female business scholar.
\end{abstract}

The Daughters of Themis network arose out of a workshop held at the University of Oslo in 2012 for female company law scholars. In a male dominated field (both in terms of scholars and the corporations that are studied), the aim of that initial network was to provide female company lawyers with a network of academics who shared the challenges and joys of being a woman in a male-dominated company law world. From that initial forum, the Daughters of Themis network was launched in 2015 and is now deliberately broad in its scope; all female scholars from any discipline exploring aspects of business are welcome to join.

Central to the network is its annual workshop. Through a selection of a limited number of participants (selected in response to an open call for papers), its aim is to provide an open, inclusive and collegiate space for the discussion of ideas. The workshop is open to female scholars only. ${ }^{3}$ While the network appreciates that there are many feminist-minded male scholars in the field, it also recognises that 'academic production is

\footnotetext{
Roseanne Russell is Lecturer in Law at Cardiff University and member of the Steering Group of Daughters of Themis. Beate Sjåfjell is Professor Dr. Juris at the University of Oslo, Faculty of Law, Head of the research group Companies, Markets and Sustainability (jus.uio.no/companies), Project Coordinator of Sustainable Market Actors for Responsible Trade (SMART) (uio.no/smart), and founding member and head of the Steering Group of Daughter of Themis (see under Networks at jus.uio. no/companies). We thank the authors of this special issue, all members of Daughters of Themis, for their contributions, all participants at the 2015 Daughters of Themis workshop for inspiring feedback, and research assistant and member of Daughters of Themis Ragnhild Lunner for excellent help with the footnotes. Contact e-mail: b.k.sjafjell@jus.uio.no

2 More information under Networks at jus.uio.no/companies

3 Although all participants at the workshop were women, two articles include work by male authors.
} 
shrouded in masculine norms and values surrounding the rational and competitive pursuit of knowledge ${ }^{4}$ and that 'for some women and a few men the competition is more akin to an obstacle race than a 300-metre sprint ${ }^{\prime} .{ }^{5}$ This is arguably especially the case in those parts of academia working on hard-core economic areas of scholarship such as business and finance. ${ }^{6}$ In contrast to the rather solitary and competitive pursuit of knowledge fostered by much of academia, the Daughters of Themis network fosters a strong sense of collegiality motivated by the sincere belief that our research and ultimately the broader academic endeavour is so much richer and enjoyable when we work together to help resolve society's great challenges.

The uniqueness of the workshop is that the small number of participants allows for intimate discussions of each other's work (typically 90 minutes per paper), genuine collaboration between scholars across disciplines, and informal support and mentoring of junior scholars by more senior participants (the network's Steering Committee is deliberately comprised of scholars at all stages of their careers and from different jurisdictions). ${ }^{7}$ Moreover, the annual workshop is carefully structured to allow for both individual and collegiate social space in recognition that this is often limited for many women juggling research careers with caring demands, and to stimulate genuine and lasting friendships and communities of support.

The intention behind this special issue is to contribute to the understanding of the relationship between women and business and how their contribution and representation is valued. Uniting these contributions, drawn from different disciplinary perspectives and with the articles covering a range of issues, is an appreciation that the current business model and culture is problematic.

The problematic nature of the current business model and culture is not limited to gender inequality. The broader issue concerns the

4 D. Knights and W. Richards, 'Sex Discrimination in UK Academia' (2003) 10(2) Gender, Work \& Organization p. 213 at 214.

5 Ibid. at 219. See also S. Winslow, 'Gender Inequality and Time Allocations Among Academic Faculty' (2010) 24(6) Gender \& Society p. 769; M. van den Brink and Y. Benschop, 'Gender practices in the construction of academic excellence: Sheep with five legs' (2011) 19(4) Organization p. 507; and M. van den Brink and Y. Benschop, 'Slaying the Seven-Headed Dragon: The Quest for Gender Change in Academia' (2012) 19(1) Gender, Work \& Organization 71.

6 As a case in point, Beate Sjåfjell is the only female company law professor in the relatively egalitarian country of Norway, and to our knowledge there are still less than five in all of the five Nordic countries together.

7 Appointed for a year at a time, with an overview of the participants available on Daughters of Themis' website, under Networks at jus.uio.no/companies (last accessed 27 Jan. 2017). 
very foundations of humanity's existence. In spite of all the business initiatives using a sustainability language ${ }^{8}$ the status quo remains very much unchanged: 'business as usual' continues, and is a very certain path towards a very uncertain future. The dire status as regards the convergence of environmental crises facing society on a global scale is encapsulated in the concept of 'planetary boundaries', first identified in the ground-breaking article by Rockström et al. in 2009, ${ }^{9}$ and updated and re-affirmed by Steffen et al. in 2015. ${ }^{10}$ Planetary boundaries define global sustainability criteria for critical environmental processes that regulate the stability of the life-support systems on Earth, defining nine parameters of the earth system to indicate a safe operating space for humanity. ${ }^{11}$ According to Steffen et al., human production and consumption is placing us in increasing or high risk in relation to at least four of the boundaries: climate change, biosphere integrity (genetic diversity, with uncertainty concerning the boundary for functional diversity), land system change, and biogeochemical cycles (phosphorus and nitrogen). ${ }^{12}$ The grand challenge of sustainability lies in securing the social foundation for humanity now and in the future, while staying within the planetary boundaries; in Kate Raworth's words: achieving a safe and just operating space for humanity. ${ }^{13}$ Business contribution to meeting this grand challenge is vital, and the questions concerning the role of gender in achieving sustainability are many. This special issue engages with some of these questions and should be perceived as the

See e.g. the approach of the World Business Council for Sustainable Development, available at wbcsd.org/Overview/Our-approach, and the SDG Business Hub, available at sdghub.com/

9 Johan Rockström et al., 'Planetary boundaries: exploring the safe operating space for humanity' (2009) 14(2) Ecology and Society, available at ecologyandsociety.org/vol14/ iss2/art32/ (last accessed 27 Jan. 2017).

10 Will Steffen et al., 'Planetary Boundaries: Guiding human development on a changing planet', (2015) 347(6223) Science, available at sciencemag.org/ content/347/6223/1259855.abstract (last accessed 27 Jan. 2017).

11 See e.g. the synthesis report of the UN Secretary-General on the post-2015 sustainable development agenda, 'The road to dignity by 2030: ending poverty, transforming all lives and protecting the planet', A/69/700 (4 December 2014) para.75, p. 18: 'To respect our planetary boundaries we need to equitably address climate change, halt biodiversity loss $[\ldots]^{\prime}$, available at www.undocs.org/A/69/700 (last accessed 27 Jan. 2017).

12 The other five being global freshwater use, ocean acidification, atmospheric aerosol loading, stratospheric ozone depletion, and cycling of phosphorus and nitrogen; Steffen et al., supra note 11 .

13 Kate Raworth, 'A safe and just space for humanity: Can we live within the doughnut?', discussion paper, (Oxfam, 2012), available at http://www.oxfam.org/sites/www. oxfam.org/files/dp-a-safe-and-just-space-for-humanity-130212-en.pdf (last accessed 27 Jan. 2017), and Melissa Leach, Kate Raworth and Johan Rockström, 'Between social and planetary boundaries: Navigating pathways in the safe and just pathway for humanity' World Social Science Report 2013: Changing Global Environments, pp. 84-90 (OECD, 2013). 
beginning of a larger discourse to which Daughters of Themis wishes to contribute.

Much of the discussions on women and business are dominated by the 'boardroom diversity' debate, which itself has at times become polarised between those who would advocate for more women directors by making 'the business case' and those who seek gender parity on boards for reasons of social justice. ${ }^{14}$ While the composition of the corporate board, as central decision-making organ, is an important issue, we are delighted that the contributors to this special issue have looked beyond the boardroom to reflect more holistically on women and their relationship with corporations and have gone considerably beyond the 'business case / social justice' binary.

Yue Ang's contribution explains how women are over-represented amongst the 'atypical' workforce, which she shows has grown in the years after the financial crisis of 2007-08. In questioning whether there is a need to step outside current modes of business, she makes the case for greater protection of atypical workers and considers the role of social entrepreneurships in achieving this.

This focus on alternative business forms is also central to the work of Aikaterini Argyrou and Stelios Charitakis who reveal the stark consequences of the Greek financial crisis on the position of women. They argue that it is not enough to rely on policy initiatives designed to guarantee formal equality for men and women in the labour market but that positive action is needed. They too see the potential in female social entrepreneurships.

María Ángeles Fernández-Izquierdo, María Jesús Muñoz-Torres, Idoya Ferrero-Ferrero and Lucía Bellés-Colomer examine the growing corporatization of the university sector and, taking inspiration from scholarship on the corporate boardroom diversity debate, show the low numbers of women on the governing bodies of Spanish public universities and why this is problematic from the perspective of sustainability. They argue that the 'scarce presence' of women in senior positions of responsibility can lead to gender imbalance in decision-making processes.

Roseanne Russell's article considers how FTSE100 companies frame discussions of boardroom diversity and reveals how considerations of 'valuing diversity', 'merit' and 'nurturing talent' are foregrounded.

$14 \quad$ Beate Sjåfjell, 'Gender Diversity in the Board Room \& Its Impacts: Is the Example of Norway a Way Forward?' (2015) 20(1) Deakin Law Review, pp. 25-52. Available at SSRN: https: / / ssrn.com/abstract=2536777 or http: / / dx.doi.org/10.2139/ssrn.2536777 (last accessed 27 Jan. 2017). 
The contribution by Rosalien Diepeveen, Tineke Lambooy and Remko Renes explores the motivations of, and measures taken by, Dutch listed companies regarding boardroom diversity. They show how diversity in its broadest sense (and not merely in terms of gender) is a key motivation, a finding shared in the analysis of FTSE100 companies by Roseanne Russell. Both the positive potential and limitations presented by viewing diversity as a matter extending beyond gender are matters that would benefit from further analysis.

We hope that this special issue encourages others to explore the link between companies, sustainability and gendered power relations. Female business scholars wishing to join Daughters of Themis are welcome to contact Beate Sjåfjell. ${ }^{15}$

15 Contact information in $\mathrm{n} 1$ above. 